\title{
Finding guidelines on social change in the two-tiered narrative and diakonia in the Gospel of John
}

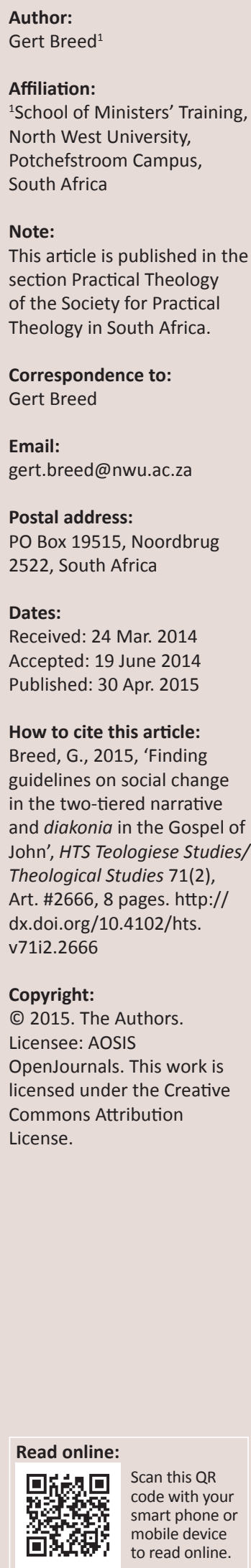

It is shown in this article that the Gospel of John describes a battle between darkness and light, life and death, chaos and God's new order. Although the certainty is given right at the beginning of the Gospel that the darkness will not overcome the light, God does not take the possibility of darkness away. Darkness in John is darkness of the mind, not seeing the light, not comprehending, not accepting and not believing the Word. The battle between light and darkness is described at two levels - the visible level that you can see with your eyes and the invisible level that only those who have been regenerated by the Spirit can see. Although it may seem that the contrary is true, God is in control of both levels. Jesus made the invisible visible with his words and deeds and, eventually, with his resurrection. The diakonoi (servants) of Jesus are called to follow him in his task to honour the father by speaking the words of the father and doing the work of the father. In doing this, they will make the invisible God visible by their diakonia (service). Real social change will take place in God's time, and he will use the diakonia of his children to bring order in the chaos, like he did in the beginning when he created the heavens and the earth. The results of the research are used to suggest guidelines on social change in South Africa.

\section{Introduction}

The Gospel of John links the coming of Jesus Christ to creation (Gn 1-2; Brown 2010:275, 277-282, 286; Evans 1993:77-79; Koester 2008:30). John shows that Jesus Christ was the one through whom everything was created. Jesus was the one through whom, in the beginning, light came into the darkness and life came into the emptiness (Jn 1). As he came to make recreation possible, He came as the light and the life for mankind (Bruner 2012:10-14). He came as the one sent by God. The whole narrative of the book is driven by the purpose of God to save his children by sending the light to the world (Jn 3:16; Koester 2008:28). In John 1, the continuity between God's purpose for creation and his sending the Word is stressed (Brown 2010:276). Koester (2008:28) remarks, 'Yet God remains hidden, his presence elusive', and all the things that he did were tied to the one he sent (Anderson 1999:34). Koester (2008:30) continues' ... the prologue helps define God's relationship to the world. God is the creator; the world is created. The world may claim independence, but this is not the case. Its existence depends upon the Word of God' (see also Bruner 2012:14).

\section{The ever-present possibility of chaos (The chaos narrative)}

As also described in Genesis, God did not take the possibility of chaos away. From the start (Jn 1:5), the assurance is given that the darkness will not overcome the light, but that does not take the presence of darkness away (Bruner 2012:18). Darkness in John is darkness of the mind, not seeing the light, not comprehending, not accepting and not believing (Manzanga 2007:10; Neyrey 2007:51). John 1:5 (KJV) clearly states, '[a]nd the light shineth in darkness; and the darkness comprehended it not'. The Greek word katalambano can also have the meaning of 'comprehension' (Köstenberger 1999:55). The object of 'comprehension' is the Word of God as embodied in Jesus Christ. Jesus said the essence of the word was that the father had sent the son to reveal the father in this world (Jn 17:4-6; Bruner 2012:983-984). This word would judge those who did not accept it in the end (Jn 12:48). Jesus also said evil was present in people's lives, because they did not accept the truth that was revealed in the son. Evil reigned in their lives in the form of sin, which enslaved them (Jn 8:34), because they believed the lies of Satan, and Satan, using the lies, murdered them $^{1}$ (Jn 8:44; 10:10; Koester 2008:74-75; Manzanga 2007:72). Chaos in somebody's life means living according to the lies of Satan and conforming to his lusts, thus having him as father (Jn 8:44; Neyrey 2007:156) and being the enemy of God (Van der Watt 2000:357-359).

1.Neyrey (2007:43) also points out that Jesus is identified by the Word 'true', which stands in contrast to 'what the author considers obsolete, defective and unreliable.' 
There is also the possibility of the progress of the darkness (evil) in one's life. It is illustrated in the life of Judas. In John $13: 2$, it is told that while supper was being served, the devil had already put it into the heart of Judas to betray Jesus; and in 13:27, it is said that the devil entered into Judas (Koester 2008:77). John states it was night when Judas went away from Jesus (Jn 13:30). According to Matthew 27:3, Judas hanged himself. Throughout the Gospel of John, the everincreasing hatred and rage of the Pharisees and other leaders towards Jesus is shown. They progressed from efforts to catch him saying something wrong (Jn 8:3-5) and making him unpopular with the crowd, to the decision to kill him, and even to kill Lazarus whom he had raised from death (Jn 12). The ever-increasing chaos in the ranks of the leaders is spelled out by their lies and conspiracies. Satan's lie, which they believed, is the same lie that Adam and Eve believed, namely that they could be God in their own lives, not trusting God's Word. Believing this lie led them to seek the praise of men and not the praise of God. The consequences of their attitudes and actions were that they were unable to believe (Jn 5:44; Koester 2008:59-65).

From one point of view, chaos reached a climax when the crowd, which had only recently honoured Jesus as King, were excited by their leaders to shout, 'Crucify Him!' Already before the confusion and lack of order among the crowd, Jesus was found guilty on the basis of a lie. Moreover, they were unable to recognise him as the Messiah, who had been sent by the father to do the work of the father and to speak the words of the father. Pilate, though having just declared him innocent, gave him over to be crucified because he feared the consequences of going against the crowd. The chaos in his mind is shown as looking after himself, being his own god, and not acting according to the truth (Culpepper 1997:25-26; Waetjen 2005:385-394). When Jesus was dying on the cross, it seems as if he was acknowledging the victory of chaos with his words, 'My God, My God, why have you forsaken me?' (see Mark 15:34; also Bruner 2012:18.)

\section{The Word that brings life (The new order narrative)}

According to Genesis 1, God spoke and his word created order in a place that was without form and void (lacking purpose and worth; 'without function'). In everything that came about because of his spoken word, he revealed himself as the creator who brought about that which is good - yes, very good (Gn 1:31)! John characterises Jesus as 'the Word'. Hebrew 1:2 says God spoke to us through his son. In the beginning, Gods word brought light and created a living space for all creatures. Genesis 2 describes creation as an action by which God created a space where man could live. Jesus came as the Word of God, in the Word was life and the life was the light for the world (Jn 1:1-5). The life in the word brought light into the darkness and thereby creating anew a living space for those who believe.

The Word has life in himself; he does not derive it from another source. Nothing in the world, including the human being, has live in it or in him. Only the Word of God can bring them life. Koester (2008:31) explains: 'This means that in John's Gospel life is understood relationally. To have life is to relate to the God who is the source of all life' (see also Van der Watt 2007:58-59). Relating to the Word as the source of life is having light in your life. Not relating to the Word is staying in the dark and being dead. Knowing and keeping the Word is to know God and loving Jesus (Jn 12:46). Jesus gave the assurance that those who kept his word would be loved by the father, and then God would come and make his home with them (Jn 14:23). Jesus promised his disciples that he would go and prepare place for them in his father's house. As in Genesis, God provides living space for those who love him; those who do not believe will stay in the darkness. $^{2}$

It is important to notice the similarities and the differences in the way that life was created in the beginning as opposed to the way new life is created according to John. In both instances, life is created by God; without him there would have been and will be no life. In both instances, life comprises more than just physical life. Physical life is the space in which real life has to be lived. Real life means living in a particular relationship with God. This relationship means being the image and representative of God (Jn 13:12-16). In the beginning, man was created within this relationship, but he willingly abandoned it. The coming of Jesus, the light, brought everyone before the decision to accept the light or to reject the light (Jn 1). Jesus said that those who accepted the light received the right to be children of God. ${ }^{3}$ You accept the light by trusting that he speaks the truth and therefore you accept the word he speaks (Jn 5:24). When you accept the word, the word must remain in you so that you will remain in Jesus (Latz 2010:161-168).

In the beginning, there was the possibility of losing the life that God had given. The new life according to John is an everlasting life. Having life means having gone permanently out of death over to life. It means you are in the hands of the father, the son and the Holy Spirit, and that it is impossible to be taken out of their hands (Jn 6).

Adam and Eve lost the life and the relationship with God by rejecting the Word of God, and by believing the opposing word, which brought the chaos of sin and death. According to John, Jesus said that one could only have life if his - Jesus' - word was abiding in him (Jn 5:38). The word was the truth, and the truth would set the one that knew it free (Jn 8:32). ${ }^{4}$ The opposing word was the word of Satan, who was a liar and a murderer from the beginning. Those who believed the lies of Satan had him as

2.See Brown (2003:277-278) for the centrality of the theme of life in the Gospel of John.

3.Neyrey (2007:37-41) points out a chiastic structure in John 1:1-18. The logic of the structure indicates that the 'giving of power to become children' is the 'key, pivotal centre and the major idea in the communication' (Idem: 41) of this passage, whilst centre and the major idea in the communication' (Idem: 41)
the second focus of the prologue is the Christological one.

4. Hoskins (2010:47-63) says that this verse connects the freedom brought by the Word to the exodus of Israel out of Egypt and to the Feast of Booths and the Passover. 
their father and were doing his will (Jn 8:44). John quotes Jesus where he described the chaos as enslavement by sin (8:34), being blind (9:39) and being murdered by Satan $(8: 44)$. In a sense, we can say that the entire Gospel is about the battle between darkness and light, chaos and order, life and death, as stated in John 1:5, 'And the light shines in the darkness, and the darkness did not overtake it.' John describes this battle at two levels, which will be discussed in the next section.

\section{Two levels in the narrative The visible level}

Researchers such as Sheridan (2012:235) have pointed out that the writer of the Gospel of John structured his narrative deliberately to have two levels. The one level consists of observable events. Jesus is shown to have been visibly present among the people. They heard his teachings and recognised their extraordinary wisdom (Mk 1:22). They drank the wine and ate the bread he created, ${ }^{5}$ but they also knew his father and mother and the town where he grew up. They knew him to be the son of a carpenter (Jn 6:42). All those things told them that he could not be the Messiah. The miracles that he did were visible signs of his capability: water turned into wine, the lame walked, the blind saw and bread was multiplied so that everyone could become satisfied. Yet, he did things that went against their tradition. He healed people on a Sabbath (Jn 5:9-18) and (according to them) did not keep the Sabbath (Jn 9:16). That brought doubt into their minds about him being the Messiah.

When he became a threat to them, it seemed that the plan of Israel's leaders to get rid of him was working out nicely. One of his disciples worked with them to take Jesus into custody (Jn 18). His other disciples left him and fled. The disciple who had said that he would die for him denied him (Jn 13:38). The leaders got people to accuse him of blasphemy and revolt. They got the crowd excited to ask for him to be crucified. Then they even persuaded Pontius Pilate to deliver him into their hands to be crucified, although the governor, a little while before, had declared Jesus innocent (Jn 18-19). In the eyes of the leaders of Israel, Jesus was just another leader of the mob and a threat to peace, someone that they had to get rid of. For all that anyone could see, Jesus died on the cross and that was all there was to the man. He was just a person who had misled the crowd into following Him, but at that moment it had all come to an end (John 19; Köstenberger 1999:185).

Nevertheless, there is another level in the narrative.

\section{The invisible level}

From the start of the Gospel, it is clear that there is another level in the narrative. This level is best described in John 1:18, where Jesus is quoted, 'no one has ever seen God; the only God, who is at the father's side, he has made him known', and in John 1:14, where the author of the Gospel says, 'And the Word became flesh and dwelt among us, and we have seen his glory, glory as of the only Son from the father, full of grace and truth.' In the Gospel, revelation and glory play a major role at the second level of the narrative. Jesus, in all that he did and said on earth, was revealing who his father was. The glory of the son and the father could be seen in this revelation. The purpose of all that the son said and did was to glorify the father. Therefore, he only taught what the father had taught him. He only spoke the words of the father and did deeds according to the will of the father (Jn 6:12). Having done all that the father had sent him to do, he asked the father to glorify him with the glory he had possessed before creation (Jn 17:1). The interpretation of Robertson (2011:319) is that John wants to show that Jesus, with his words and deeds, was busy with 'the inauguration of an alternative reality, the reign of God ...' Robertson continues, to 'believe in "the Son of Man" (Jn 9:35) is to affirm that this new reality that Jesus incarnates and reveals is truly from God'.

Not everyone that sees Jesus and his works and hears his words understands the revelation and sees the glory (Jn 8:33). A major theme throughout the Gospel of John is the contrast between those on the one side who see, hear, understand and believe, and those who see and hear, but do not understand or grasp the real depth of what they see, and therefore they do not believe (Van der Watt 2009:301-302). The contrast becomes very clear in John 9, where it is described how Jesus opened a blind man's eyes. At first, although the man only saw Jesus as a prophet, he knew that no one could open a blind man's eyes if it was not given to him by God (Cho 2006:193). The Pharisees, despite the evidence of the man and his parents, could not accept the revelation of God in the healing (Meyers 2012:148-151). The once blind man pronounced his wonderment about their blindness by exclaiming:

Why, this is an amazing thing! You do not know where he comes from, and yet he opened my eyes. We know that God does not listen to sinners, but if anyone is a worshiper of God and does his will, God listens to him. Never since the world began has it been heard that anyone opened the eyes of a man born blind. If this man were not from God, he could do nothing. (Jn 9:30-33)

When Jesus met the blind man again, he led him to believe that Jesus was the Messiah. About the Pharisees he said, 'For judgment I came into this world, that those who do not see may see, and those who see may become blind' (Jn 9:39). Neyrey (2007:176) sees John 9 as a forensic process where Jesus was the accused, the blind man was the witness and the Pharisees were the judges. The judges found the blind man guilty and expelled him from the temple; they also found Jesus guilty. What they did not see was that there was another forensic process. In that process, they were the accused and the final predict over them was that they, while thinking they could see, were blind to the true narrative (Koester 2008:68-70).

In John 12, there is another occurrence of the levels of visibility and invisibility in the narrative. On the one hand, 
Jesus was honoured as King by the people; on the other, his coming suffering and death was predicted in various ways (Culpepper 1997:23; Meyers 2012:157-158). Whilst Jesus was talking to the people, some Greeks came with the request to speak to Jesus. When Jesus heard about their request, he reacted with the words:

the hour has come for the Son of Man to be glorified. Truly, truly, I say to you, unless a grain of wheat falls into the earth and dies, it remains alone; but if it dies, it bears much fruit. (Jn 12:23, 24)

It is clear that John conveys the idea that Jesus understood the request of the Greeks as a turning point in his ministry (Pate 2011:138). The hour that had come was the hour of his final suffering, deepest humiliation and his death on the cross. It was the hour in which his enemies would get what they wanted and he would seemingly be powerless in their hands. Yet Jesus called this hour the hour of his glorification. He also said that the ruler of the world would be judged and cast out in that hour, and when he would be lifted up (referring both to his crucifixion and ascendance), he would draw all people to him. It is clear that Jesus' conviction was that his life was predetermined and that the victory over the chaotic powers was certain. His crucifixion and resurrection were the final deeds of God to enable victory over the chaos (Breed 2014; Ellens 2010:78-79).

Even the true followers of Jesus are shown as not fully comprehending the invisible level of the narrative (Jn $8: 27 ; 10: 6 ; 12: 16 ; 13: 7 ; 13: 28 ; 20: 9)$. Only later on did they understand the things they had not understood at first (Jn 20:9) In John 16:29, the disciples exclaim, 'ah, now you are speaking plainly and not using figurative speech!' The time between Jesus' death and his appearance to his followers was a time of confusion (chaos). Thomas can serve as an example. He said that he would not believe that Jesus had been raised out of death before he saw him. When Jesus showed him his hands and feet and invited him to come and touch him, Thomas understood what he was unable to understand all the time he was with Jesus, and he confessed it with a few but meaningful words, 'My Lord and my God' (Koester 2008:126-127; Sylva 2013:91-99).

The history of the resurrection of Jesus brings the two levels of the narrative visibly together. Everyone that saw him after his resurrection could see, understand and believe (Koester 2008:127). Jesus' greeting to his disciples on two of the occasions he revealed him to them is important. He said to them, 'peace be with you!' (See Jn 19:20, 21 - NIV). Kok (2011) comments on Jesus' appearance to his disciples as follows:

Jesus surprisingly makes himself visible to the disciples, who still are caught up in fear and hide behind closed doors. In the prologue (John 1:1-18) John presented Jesus as the life-giving Word, associate creator from the dawn of time who now as resurrected Son of God utters life creating words. (p. 136)

With his resurrection, Jesus created a new living space for his disciples. This living space was the peace he was giving them in the midst of possible persecution and fear (see Van der Watt 2007:67).

\section{God in control of both levels of the narrative}

Throughout the Gospel, God the father and Jesus, as the one sent by the father, are shown as being in control of both levels of the narrative. Already at the beginning of the Gospel, the author announces that Jesus was the one that would baptise with the Spirit. Jesus did that symbolically after he had been raised from death by breathing on them (Jn 20:22). The author speaks from the certainty of Jesus' victory and that all things would happen according to God's plan. John's use of the word 'hour' shows God in full control, even in control of the agents of chaos. Jesus could speak to the Samaritan woman about an hour that will come, 'when the true worshippers will worship the father in spirit and truth' (Jn 4:23). He could tell the people about an hour 'when the dead will hear the voice of the Son of God, and those who hear will live' (Jn 5:25). The leaders of Israel tried to arrest him, 'but no one laid a hand on him, because his hour had not yet come' (Jn 7: 30; also 8: 20). When the hour came, Jesus drank the cup willingly knowing that it was necessary so that the kingdom of God could come in the chaos of a sinful world. Jesus knew that Judas would betray him and he told him to go ahead and do what he planned to do (Jn $6: 71 ; 13: 26$ ). When Judas came with the band to arrest him, he did not try to hide, but went to them out of his own free will. Even in that moment before his arrest, he revealed the power of God. When he asked them who they were looking for, they said 'Jesus of Nazareth.' Jesus used the words that God had used to reveal him to Moses. He said, 'I am' ('Ego eimi'). John describes the next moments in a way that there can be no misunderstanding that Jesus was more than just a mere man. When he said, 'I am' (Jn 18:6), all the soldiers fell to the ground. They certainly experienced something of God's power at that moment. Again John painted Jesus as the one in control of the situation (Meyers 2012:159). Jesus also told Pilate that his kingdom was not from this world; therefore, his followers did not fight (Jn 18:36). He gave himself in their hands to become the King of kings by dying on the cross.

In his last moments alive on the cross, Jesus said (Jn 19:30), 'it is finished'. He deliberately finished the work that made recreation of the world possible. God used the enemy to help Jesus finish his work of redemption. God's enemies thought they were in control, they thought their plans were working and they thought they had got rid of him. However, they were only part of God's plan, and He used their plans to finish his plan (Bruner 2012:784).

As in creation, the Spirit is involved in the penetration of the chaos, the darkness in men. No one can enter the kingdom except by being born again from above by the Spirit of God (Jn 3). This is where the two levels of the narrative meet for a person, and how it happens is as great a mystery as the wind blowing, as John reflects, 'the wind blows where it wishes, and you hear its sound, but you do not know where it comes from or where it goes. So it is with everyone who is born of 
the Spirit' (Jn 3:8). If you are not born again, you will not understand the things of God. Those who accept the light, are the ones who believe the word and they receive the right to become children of God, but they 'were born, not of blood, nor of the will of the flesh, nor of the will of man, but of God' (John 1:13; see also Van der Watt 2007:55).

The people who ate from the bread and the fish that Jesus multiplied, came searching for him and wanted to make him King, because He had given them food to eat (Jn 6:26). Jesus told them that $\mathrm{He}$ is the bread of life from the father, and they have to eat his body and drink his blood to participate in real life (Jn 6:53). The Jews could not understand what he meant and were murmuring against him; they only understood the visible part of what was happening, that is the bread he gave them. Jesus invited them to come to him and to believe in him, but many did not accept his invitation (Brown 2003:148). Jesus explained that no person could come to him except if the father would draw such a person to Jesus (Jn 6:44). To be able to come to Jesus is granted to you by the father (Jn 6:65) and this is done through the Spirit of God. The Spirit gives life, no man can become alive on his one (Jn 6:63). The Spirit works through the Word of Jesus (Jn 6:63). Human competence can do nothing in this regard. God's Spirit can, 'and the instrument that God's Spirit uses to bring God's Word to human beings is the word of and about the incarnated (enfleshed) Jesus of Nazareth' (Bruner 2012:448). God is in control of who will believe, who will see and hear.

\section{Invisible made visible}

Chan (2013:57) says that after Jesus' death the narrative in John presents two patterns of discipleship, namely '(a) those whose faith is based on seeing the resurrected Jesus, and (b) those who follow him even without having seen his resurrected body'. He shows that John's purpose, as described in John 20:30-31, is to live by the last-mentioned pattern of faith believing without seeing. He (Chan 2013) points out that John narrates different reactions to Jesus' death and resurrection. Mary, Thomas and Peter were able to believe only after they had seen the resurrected Jesus. The beloved disciple, Joseph of Arimathea and Nicodemus believed before they had seen Jesus alive. At the empty grave, the beloved disciple saw the 'face cloth' and he believed, which is in contrast to Peter, who just saw the 'linen cloth' - no mention is made of him understanding the significance of what he saw (Hartin 1990:55; Sylva 2013:99). It was the same with Mary who saw Jesus, but did not recognise him (Chan 2013:72). Chan (2013:72) indicates that the verb strapheo is used in both verse 14 and 16, indicating an action of Mary. After she had spoken to the angels, she turned around (strapheo) and saw Jesus, but she thought he was the gardener. Then Jesus called her name. Again it is said that she turned (strapheo). Chan's point is that there is a possibility that strapheo indicates a spiritual turn around the second time (vs. 16) (Chan 2013:67). He points to John 12:40 for confirmation of this theory. According to John 12:40, Jesus quoted Isiah, who said, 'he has blinded their eyes and hardened their heart, lest they see with their eyes, and understand with their heart, and turn (strapheo), and I would heal them'. The opposite happened to Mary. She heard the Lord calling her name, turned around in her heart, saw him, understood and consequently believed with joy and peace. As has been said, only the father can give this understanding and faith to somebody through the work of the Holy Spirit (contra Brown 2003:149-150). The fact is, at that moment, the light of the word came into the heart and mind of Mary so that she could comprehend God's plan that had been hidden to her up to that moment (Koester 2008:123-126). The readers of John's Gospel are prompted to believe without seeing; or, when they did not see in unbelief at first, to turn around and see (Sylva 2013:99).

John 12 also describes turning and not turning, seeing and not seeing. In addition, the way in which God brought people to see and understand after Jesus' ascension is also described in John 12 . The invisible was made visible to some by the Holy Spirit without them seeing Jesus and to others by seeing the resurrected Lord. But how will the invisible be made visible when Jesus is not bodily present on earth anymore?

John gives the answer in John $12{ }_{1}^{6}$ where various groups of people are described in their relationship to Jesus (Sheridan 2012:216-218). Firstly, there were Mary and Martha, women that served Jesus each of them in her own way. Judas and the chief priests were there planning, each of them in their own way, to kill Jesus. There were the crowds that were excited about the raising of Lazarus from death, and that came to see Jesus and Lazarus; they also came for the feast. They honoured Jesus as the King of Israel who came in the name of the Lord. Then there were those who saw and understood, but could not bring themselves to confess their beliefs, out of fear and their love of the honour man can give. It is as if John takes his readers into the milling crowd around Jesus, some who were still in the dark and some who had already come to the light of the world (Sheridan 2012:219-222).

In the middle of this description, John describes a seemingly minor incident. ${ }^{7}$ Some Greeks came to Philip and asked to see Jesus. Phillip told Andrew, and the two of them went to tell Jesus. Then a surprising reaction of Jesus is recorded (Köstenberger 1999:137-139; Sheridan 2012:231). The text has a deliberate structure:

25 And Jesus answered them, 'The hour has come for the Son of Man to be glorified. Truly, truly, I say to you, unless a grain of wheat falls into the earth and dies, it remains alone; but if it dies, it bears much fruit.

26 Whoever loves his life loses it and whoever hates his life in this world will keep it for eternal life. If anyone serves me, he must follow me; and where I am, there will my servant be also. If anyone serves me, the Father will honor him.

27 Now is my soul troubled. And what shall I say? "Father, save me from this hour?" But for this purpose I have come to this hour. Father, glorify your name'.

6.See Meyers (2012:154-155) for, what she calls, the 'pivotal function' of John 12 in the gospel.

7.This discussion will build on, without repeating, my article on the meaning of the diakon word group in John 12 (Breed 2014). 
The Greeks' request made Jesus aware that his hour had come (Sheridan 2012:233). That was the hour in which the grain (Jesus) had to die so that it could bear much fruit (Joh 12:25). Because of the prospect, Jesus' soul was troubled and he wondered if he could ask the father to save him from that hour (vs 27a). However, he realised that the entire purpose of his coming was captured in that hour. Therefore, he declared him willing to do whatever would glorify the name of his father (vs 27b). That hour would also be the hour of his glorification, because he would complete his work (Carter 2008:316). In the middle of Jesus' description of the hour that dawned for him and his reaction to the demands of that hour, Jesus talked to his servants (diakonos; vs 26). To them a new hour had also come, as they were part of that hour in Jesus' life (see Breed 2014:3). That hour demanded from them willingness to lose their lives to glorify Jesus and the father (vs 25), because if someone wanted to serve (diakoneo) Jesus, he had to be willing to follow Jesus (Du Rand 1991:318; Van der Watt 2000:108). Serving and following Jesus has a unique character; it is closely related to the request of the Greeks. The Greeks were representatives of those about whom the Pharisees prophesied, 'look, the world has gone after him', (vs 19) and about whom Jesus said, 'And I, when I am lifted up from the earth, will draw all people to myself' (vs 32). Phillip and Andrew represented all the followers of Jesus who would from then on lead the people to Jesus (Waetjen 2005:294-295). ${ }^{8}$

In a previous article, I made an in-depth study of John 12:26 in the context of John's Gospel (Breed 2014). In that article, I wrote in length on the meaning of the words diakoneo and akoloutheo as used in John 12, and also about what it means to be where Jesus is and to be honoured by the father (vs 26; see also Van der Watt 2000:331-333). What is important for this research is to compare Jesus' words that his diakonos would be where he would be (vs 26) with verses $44-50$. John 12 is the conclusion of Jesus' work amongst the crowds; from Chapter 13 it is recorded how he worked only with his disciples. He prepared them for the work ahead of them when he would be with his father (Van der Watt 2008:91).

Seeing the following structure in John 12 is important:

$\longrightarrow$ Vs 1-19 Various people's attitude towards Jesus (cf. Köstenberger, 1999:132-136).

$>$ Vs 20-33 The hour that came, Jesus' reaction to the hour and the result of Jesus' work in the hour. The relationship between Jesus and his disciples, and between the work of the disciples and the work of Jesus (Köstenberger, 1999:137-138).

Vs 34-43 Various people's reaction to Jesus' teaching about the hour and the voice of the Father (Köstenberger 1999:139-140).

$>$ Vs 44-50 Jesus' work, the purpose of his coming and the relationship between Jesus and the father, between the work of Jesus and the work of the father, and the result of Jesus' work in people's lives.
From this structure, it is clear that John deliberately connects vs $20-33$ to vs $44-50$ for his readers. When we ask about the meaning of Jesus' words in vs 26 ('and where I am, there will my servant [diakonos] be also'), we can expect that vs 44-50 will help us understand the meaning of his words. In fact, we can say that what Jesus said in vs $44-50$ about the relationship between him and his father, and between his work and the work of the father, would also be true about the disciples and the relationship of their work to Jesus and the father (Koester 2008:128-129; Köstenberger \& Swain 2008:69-70; Meyers 2012:162-163). Du Rand (1991:312-317), making the same point about discipleship in John's Gospel says, 'discipleship is defined as a real sharing in the life and destiny of Jesus and a service of witness', and, 'The parallel between Jesus and his father should be projected on the relationship between Jesus and his disciples'. Commenting on Jesus' sending of the disciples recorded in John 17:18, Van der Merwe (1997:340) says ${ }^{9}$ the following:

This would imply that the Jesus-disciples relationship (discipleship) is placed parallel to the Father-Son relationship. If discipleship is thus seated in and based on the Father-Son relationship, then the mission of Jesus constitutes the theological setting and framework in which Johannine discipleship should be interpreted.

In the above-mentioned relationship and in the enablement of the disciples to speak the words and do the deeds of the Father and the Son, the Holy Spirit would play a decisive role. According to John 14:19-26, after Jesus' ascension, the relationship between the disciples and the son and the father would be as close as Jesus predicted, 'In that day you will know that I am in my father, and you in me, and I in you' (Jn 14:20). Jesus would manifest him to those who loved him (Jn 14:21). He would not leave them as orphans but send the Holy Spirit (Jn 4:16-18), who would be in them, teach them the words of Jesus, empower them to do the works of Jesus and keep the words of Jesus (Jn 4:12). Eventually, the purpose of all those deeds would be that the father would be glorified in the son (Jn 4:13; Köstenberger \& Swain 2008: 143-148; Shillington 2012:34-36).

Of importance now is Jesus' words recorded in John 12:45. He said, 'and whoever sees me sees Him who sent me'. The one who served and followed Jesus would be where Jesus was (Jn 12:26). In that instance, the diakonos would make Jesus and the father visible with their diakonia ${ }^{10}$ (Van der Merwe 1997:343). Jesus was very clear that the authority of his teachings and his deeds rested in the fact that his words were the father's words and that his deeds were done in obedience to the father. Likewise, the words and deeds of Jesus' diakonoi

\footnotetext{
9.Compare also Peterson (2013) for discussion of the unity between Christ and $\mathrm{Hi}$ followers.

10.The results of the latest research on the meaning of the diakon word group are discussed and used in the following articles: Breed and Breed 2010; Breed, 2012a:1-8; Breed 2012b:4, 5; Breed 2014. See also Arndt, Danker \& Bauer 2000 Collins 1990; Donfried 1990; Gooder 2006; Hannaford 2005; Hentschel 2007; Latvus 2008.

On the basis of these research it is accepted that the diakon word group does not have the exclusive or general meaning of humble service motivated by love for one's fellow man, but also appears in the semantic context of representative, for one's fellow man, but also appears in the semantic context of representative,
messenger and envoy. The diakon word group can be used to describe the whole messenger and envoy. The diakon word group can be used to describe the whole
ministry, as well as every part of the ministry of the church (Breed \& Breed 2010).
} 
will have authority and will reflect the image of the Father and the Son as long as they are deeds and words of the Father and the Son (Bruner 2012:741). Being a true servant (diakonos) of Jesus, truly serving (diakoneo) him, means to die (Jn 12:25) in the sense that you do not speak your own words and do your own deeds. If you die like this you will receive real life, that is, God will become visible in your life because you are doing his work and saying his words. The invisible God becomes visible in the diakonia of his diakonoi. The same point was made by Jesus when he said, 'by this all people will know that you are my disciples, if you have love for one another' (Jn 13:35). Jesus made the invisible visible with his resurrection. The diakonoi will make the invisible visible with their resurrection from death that will be visible in their words and deeds of love (Du Rand 1991:318). With their diakonia of words and deeds, they will proclaim the word and spread the light, but according to John's description in John 12 and 20, there will be different ways in which people will come to faith or not come to faith. Some will be like Mary and Peter, who at first saw but did not really see. Some will be like the beloved disciple and Joseph of Arimathea, for whom the light dawned immediately, before others could see (Koester 2008:127). Still others, like some of the Pharisees, will never see the light.

From another point of view, one could say that the diakonoi will make the reign of King Jesus visible with their diakonia. John 12 depicts Jesus as King, the crowd honour him as King, and his crucifixion is portrayed as an enthronement and as a victory over the enemy (Jn 12). The disciples became part of this reign by dying to themselves. Jesus conquered the enemy and by dying on the cross, by being seemingly weak, he attracted people to him, and is still attracting people to him. On the cross the depth of God's love, as well as the magnitude of his power, became visible. In the same vein, the depth of God's love and the magnitude of his power will be visible when the followers of Jesus crucify themselves in their diakonia. In that way God can bring order in the chaos of somebody's life, in a marriage, a family, a congregation, in a group of people or a country.

\section{Guidelines for social change}

It is not possible to discuss the situation in South Africa indepth in this article. The purpose of this article is only to give some guidelines on which model can be founded to facilitate social change in South Africa. The following guidelines on social change can be gleaned from the foregoing research:

- God will restore order to the apparent chaos in his time. It may even get more chaotic, but the darkness will not overcome the light enduringly. God can use even the most evil plans to bring the future of South Africa to the end he planned. The people of South Africa already witnessed the fall of the chaos of apartheid. Though it seems as if the new era only brought its own chaos, we trust God to create order in his own way and in his own time.

- Anybody that predicts the future of South Africa with $100 \%$ certainty, or that talks or preaches about God's will as if he or she could fathom God's plans fully, would probably be amazed at God's ways. The way to social change is via the principles in God's Word.

- This means that God's children can always expect the unexpected from the almighty God. ${ }^{11}$

- The battle is waged for the hearts and minds of the people. To give people running water, electricity, medical care and work is a good start. Order will only be created out of the chaos of murder, rape and domestic violence, when people accept the Word of God as the light of their lives. Giving help only at a physical level or preaching a social or prosperity Gospel is serving only at the visible level. Really serving (diakoneo) means leading people to see God's invisible narrative in their lives.

- An integral part of the church's task is leading people to the decision to serve Jesus and follow him so that they can be where he is in his commitment to the father and in the unity between the triune $\operatorname{God}^{12}$ and his people. When the church is performing this calling faithfully, people will come to the point that they serve Jesus, even if it means that they may lose their lives. These people will then also serve other people without self-interest, and thus contribute to social change.

- The visible narrative in the South African society is not the only narrative there is. God is executing his plan, and the visible events are merely a part of his plan. People who live in fear and hopelessness must be guided to believe in God, who reigns, and then to search for the wisdom of the Holy Spirit to understand the ongoing invisible narrative (see Köstenberger \& Swain 2008:164).

- The resurrection of Jesus Christ and the fact that He reigns as the living God, are the essence of the message of his diakonoi. Work towards social change is based on the certainty that the Holy Spirit can change a person or a group of people as radically as a dead body will be changed if it is raised from death to become alive. ${ }^{13}$

- The diakonia of the followers of Jesus entails that they, under the guidance of the Holy Spirit, speak the words and do the deeds of Jesus and the father (Köstenberger 1999:145-148). The church is then doing the diakonia of the Triune God and can depend on him to restore order to the chaos and bring light to the darkness (see Koester 2008:129,130).

- God's invisible narrative in South-Africa is made visible by the diakonia of the followers of Jesus. In fact, God himself is visible in the words and deeds of his children. The diakonia consists of everything they do in accordance

11.Achtemeier (1981:160) phrases this principle, "God is not trapped by history and freely changes the meaning of the past by his acts in the present as he moves his creation into the future where He will assume visible rule. Thus, God's relationship to the past cannot be viewed with complacency. Rather, we must be open to the new things $\mathrm{He}$ will yet bring forth as He guides history along the path he has chosen for it'.

12.See Köstenberger and Swain (2008:165-186) for a thorough discussion of the Trinity in the Gospel of John.

13.See Holmes (2012) who stresses the fact that Jesus is living and present, still working to call, save and send his children. Purves (2010:65-153) spells out the practical implications for the ministry based on the fact that Jesus is alive and practical implications for the ministry based on the fact that Jesus is alive and
present. 
with the Bible to honour God and every word they speak according to his will (see Van der Watt 2000:282-284).

- God uses the diakonia of his children to draw people to the living King, Jesus Christ, and in doing that, he lets his kingdom come in their hearts and in society and restore order in the chaos.

\section{Acknowledgements Competing interests}

The author declares that he has no financial or personal relationship(s) that may have inappropriately influenced him in writing this article.

\section{References}

Achtemeier, J., 1981, 'The ministry of Jesus in the synoptic Gospels', Interpretation 35(2), 157-169. http://dx.doi.org/10.1177/002096438103500205

Anderson, P.N., 1999, 'The having-sent-me father: aspects of agency, encounter, and irony in the Johannine father-son relationship', Semeia 85, 33-57.

Arndt, W., Danker, F.W. \& Bauer, W., 2000, A Greek-English lexicon of the New Testament and other early Christian literature: Based on Walter Baur's GriechischesDeutsches Wörterbuch zu den Schriften des Neuen Testaments und der übrigen urchristlichen Literatur, 3rd rev. edn., University of Chicago Press, Chicago.

Breed, G., 2012a, 'Nuut gedink oor die wese en inhoud van die dienswerk van die diaken', HTS Teologiese Studies/Theological Studies 68(1), 1-8.

Breed, G., 2012b, " $n$ Begronde bedieningsmodel vir die diakonia van die gemeente', HTS Teologiese Studies/Theological Studies 68(2), 1-11.

Breed, G., 2014, 'The meaning of the diakon word group in John 12:26 applied to the ministry in congregations', Verbum et Ecclesia 35(1), Art. \#844, 8 pages.

Breed, G. \& Breed, D.G., 2010, 'Besinning oor die diakonale dienswerk na aanleiding van Handelinge 6:1-7', In Die Skriflig 44(3/4), 627-653.

Brown, J.K., 2010, 'Creation's renewal in the Gospel of John', The catholic biblical quarterly 72, 275-290.

Brown, T.G., 2003, Spirit in the writings of John, Johannine pneumatology in socialscientific perspective, T\&T Clark, London.

Bruner, F.D., 2012, The Gospel of John: A commentary, Eerdmans, Grand Rapids.

Carter, W., 2008, John and empire, initial explorations, T\&T Clark, New York.

Chan, K., 2013, 'John 19:38-20:31: Discipleship after the death of Jesus', Conspectus $15,57-83$.

Cho, S., 2006, Jesus as prophet in the fourth gospel, Sheffield Phoenix Press, Sheffield.

Collins, J.N., 1990, Diakonia: Re-interpreting the ancient sources, Oxford University Press, Oxford.

Culpepper, R.A., 1997, 'The theology of the Johannine passion narrative: John 19:16b-30', Neotestamentica 31(1), 21-37.

Donfried, K.P., 1990, 'Ministry: Rethinking the term diakonia', Concordia Theological Quarterly 56(1), 1-15.

Du Rand, J.A., 1991, 'Perspectives on Johannine discipleship according to the farewell discourses', Neotestamentica 25(2), 311-325.

Ellens, J.H., 2010, The Son of man in the gospel of John, Sheffield Phoenix Press, Sheffield.
Evans, C.A., 1993, 'Word and glory. On the exegetical and theological background of John's prologue', Journal for the study of the New Testament, Supplement Series 89, Sheffield Academic Press, Sheffield.

Gooder, P., 2006, 'Diakonia in the New Testament: A dialogue with John N. Collins', Ecclesiology 3(1), 33-56. http://dx.doi.org/10.1177/1744136606067678

Hannaford, R., 2005, 'Representation and the theology of ministry', Ecclesiology 1(2), 75-94. http://dx.doi.org/10.1177/1744136605051888

Hartin, P.J., 1990, 'The role of Peter in the fourth gospel', Neotestamentica 24(1), 49-61.

Hentschel, K., 2007, Diakonia im Neuen Testament: Studien zur Semantik unter besonderer Berücksichtigung der Rolle von Frauen, Mohr Siebeck, Tübingen.

Holmes, C., 2012, 'The ministry of the risen Lord. What Jesus is doing', Christian Century 19, 26-29.

Hoskins, P.M., 2010, 'Freedom from slavery to sin and the devil: John 8:31-47 and the Passover theme of the gospel of John', Trinity Journal 31, 47-63.

Koester, C.R., 2008, The Word of life: A theology of John's gospel. Michigan: Eerdmans.

Kok, K., 2011, 'The chaos of the cross as the fractal of life: the birth of the post resurrection, missional dimension in John', Neotestamenica 45(1), 130-145.

Köstenberger, A.J., 1999, Encountering John, Baker Academic, Grand Rapids.

Köstenberger, A.J. \& Swain, S.R., 2008, Father, Son and Spirit. The trinity and John's gospel, Apollos, Downers Grove.

Latvus, K., 2008, 'The paradigm challenged. A new analysis of the origin of diakonia' Studia Theologica 62, 142-157. http://dx.doi.org/10.1080/00393380802 Studia
559816

Latz, A.B., 2010, 'Short note toward a theology of abiding in John's Gospel', Journal of Theological Interpretation 4, 161-168.

Manzanga, P., 2007, A study of the background of the concepts 'life' and 'light' in the prologue of the fourth gospel, MA dissertation, North-West University, Potchefstroom.

Meyers, A.D., 2012, Characterizing Jesus, a rhetorical analysis on the fourth gospel's use of Scripture in its presentation of Jesus, T\&T Clark, New York.

Neyrey, J.H., 2007, The gospel of John, Cambridge University Press, Cambridge.

Pate, M.C., 2011, The writings of John, a survey of the Gospels, epistles and apocalypse, Zondervan, Grand Rapids.

Peterson, R.A., 2013, 'Union with Christ in the gospel of John', Presbyterion 39(1), 9-29.

Purves, A., 2010, The resurrection of ministry, serving in the hope of the risen Lord, IVP Books, Downers Grove.

Robertson, S., 2011, 'Sonship in the Gospel of John', Asia Journal of Theology 25(2), 315-333.

Sheridan, R., 2012, Retelling Scripture: "The Jews" and the scriptural citations in John 1:19-12:15, Brill, Boston.

Shillington, V.G., 2012, 'The Spirit-Paraclete as Jesus' alter ego in the fourth gospel (John 14-16)', Vision 13(1), 31-39.

Sylva, D., 2013, Thomas - love as strong as death: Faith and commitment in the fourth gospel, Bloomsbury, London.

Van der Merwe, D.G., 1997, 'Towards a theological understanding of Johannine discipleship', Neotestamentica 31(2), 339-359.

Van der Watt, J.G. 2000, Family of the King. Dynamics of metaphor in the Gospel according to John, Brill, Leiden.

Van der Watt, J.G. 2007, An introduction to the Johannine gospel and letters, T\&T Clark, London.

Van der Watt, J.G., 2008, 'Johannine style: Some initial remarks on the functional use of repetition in the Gospel according to John', In die Skriflig 42(1), 75-99. http:// dx.doi.org/10.4102/ids.v42i1.258

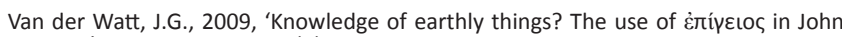
3:12', Neotestamenica 43(2), 289-310.

Waetjen, H.C., 2005, The gospel of the beloved disciple, T\&T Clark, New York. 